\title{
Perception of Street Vendors and their Effect on Urban Settings in Portobello Road, London
}

\begin{tabular}{|r|l|}
\hline Journal: & Archnet-IJAR: International Journal of Architectural Research \\
\hline Manuscript ID & ARCH-12-2020-0294.R5 \\
\hline Manuscript Type: & Research Paper \\
\hline Keywords: & $\begin{array}{l}\text { Street vendors, street markets, urban environment, perception, } \\
\text { acceptance }\end{array}$ \\
\hline \multicolumn{2}{|l}{} \\
\hline
\end{tabular}

\section{SCHOLARONE \\ Manuscripts}




\begin{abstract}
A significant and important part of our urban areas are streets, they cater to our leisure, social and functional needs. There are many debates concerning street vendors; on one hand, there are those who argue against them because they believe they create problems and should be abolished, and on the other hand, there are arguments that defend them and believe that they are vital to the street life. This paper aims to identify people's perception and acceptance of street vending and its effect on experience of the street. Observations and user interviews were undertaken in Portobello and Golborne Road to explore the influence of street vendors on urban settings and analyze their vending patterns and their relationship with urban users. Findings state that street vending takes up a large part in the liveliness and attractiveness of the market in London. People tend to accept street vendors because they have many benefits for vitality and liveliness of the urban environment, however they sometimes cause problems with ease of mobility in the area for pedestrians and the public in general.
\end{abstract}

Keywords: Street vendors; street markets; urban environment; perception; acceptance

\title{
1. Introduction
}

One cannot deny the fact that streets are the most important part of our public space; it is the most accessible part of the urban space (Appleyard, 1981). Streets around the world embrace different uses and have different forms, this helps in giving the city identity and in creating sense of place (Lynch, 1960; Cullen, 1971). Streets over time become rich, diverse, and spatially unique due to the daily life that exists within it (Zhong and Tan, 2020). One of the most common scenes in cities is the street market, where vendors either formally or informally sell all types of goods (Crawford, 1999). Street vendors can understand the potential of public space and use them commercially, and they are able to improve the attractiveness of market areas (Colin, 2018). Even though hawkers, vendors and markets have been argued to 
create nuisance in the city and might be visually irritating, they perform important functions and roles for the urban dwellers (Jacobs, 1961; Crawford, 1999; Southworth, 2005). Street vendors exist in almost all countries around the world; street vendors don't only occupy the sidewalk but in many cases also a lane or more from the street (Refaat and Kafafy, 2014). This in turn forces pedestrians off sidewalks, which increases their vulnerability risking their lives and increases the risk of accidents (Yatmo, 2008). Moreover, street vendors generally have been accused of disrupting the visual order of the environment (Yatmo, 2009). Market areas are not only regarded as shopping areas, they are perceived symbolically, mentally and physically as public spaces by the community. Understanding of these spaces differs from one person to another, whether they are an occasional visitor, shopper, vendor or even a city official. They are spaces which foster a cosmopolitan civic environment, mobility and social inclusion (Gvion, 2017). They also help in reviving parts of the city, but some British open markets are seen by some as dirty, uncontrollable, and inexpensive working-class spaces, which are operated by rude and loud traders (Gonzalez and Waley, 2012).

Over the past 20 years, UK markets have been under threat, some even closing, they have been lacking local authorities' investment (Gonzalez and Waley, 2012; Watson, 2009). They are places of cultural heritage, transmitting local traditions, culture, and history (Pang and Sterling 2013). Besides, vendors offer alternative to wholesale commodity usually at better prices and enables engagements between people from diverse backgrounds. For some people, especially elder groups of the society, the market is a crucial way to maintain social relationships and generating a sense of attachment and belongingness (Ünlü-Yücesoy, 2013; Watson, 2009). Openness of the market and proximity of the vendors' stalls to one another increases the encounters between people, helps create communal ties, public familiarity, and a feeling of comfortable "co-presence" (Spierings et al, 2016; Watson 2009). It is undeniable that street vendors create vitality within the streetscape, however their existence in the urban 
space is regarded as a nuisance, unplanned or out of place element (Hough, 1990; Creswell, 1996; Yatmo, 2008). Though, we must take into consideration the locality's character and identity of the place that could be changed with the removal of streets vendors. Besides, an activity or an object can become 'out of place' and 'in place' depending on the context. It also depends on the time of day, Yatmo (2009) found that people in Jakarta evaluated vendors as an 'out of place' element differently from day to night. There are many arguments that justify proliferation and continuation of street vending. Street vendors contribute directly to the economic activity and bring life to dull streets (Bromley, 2000). Even though street vending causes congestion and problems with the traffic flow, it is important to note that people attract other people, by activities and they enjoy unexpected concurrences (Whyte, 1988; Gehl, 2011).

There are also many arguments which are against street vending, though they are often more trivial and specific than those in favor. One of the main concerns caused by street vendors is that they usually concentrate heavily in a few locations and don't spread evenly across the city (Bromley, 2000). Also, some storeowners feel threatened by the unfair competition with them, since in some countries they don't pay taxes or rent and leads them to selling at cheaper prices (Bostic et al., 2016). Additionally, they are not always regarded as creating safe environments, since they generate congestion burglary, pickpocketing, armed assaults, and snatch thefts could easily occur in their settings. Moreover, vendors are considered unsightly and generate a lot of noise, and them and their customers leave garbage all over the street. They are often viewed as an element of disorder be the urban elite (Bromley, 2000). It is important to further investigate to help understand how street vendors, which are considered by many as 'out of place' elements, are perceived in everyday practice (Yatmo, 2009). Street vendors have a strong effect on the public realm and studying them further in new contexts is important. Moreover, they have been seen to lead to many benefits in the UK whether social, economic or political, therefore their presence is important and finding ways to even improve them is 
crucial. To contribute to this important and valid debate, this paper aimed to explore the influence of street vendors on urban settings, and people's perception of street vending and their acceptance.

\section{Factors for Analyzing Street Vending}

It is important to reassess street vendors as an 'out of place' urban elements and provide a theoretical basis for dealing with unwanted elements. Urban planners should pay more attention to the context in which the street vendors exist in and their relationship with the surroundings, and deal with any problems raised. The whole framework needs to be more inclusive of these unwanted elements and we must learn how to integrate these spaces in our urban space. The following are factors that were found through literature to have an important effect on street vending, markets and everyday successful urban spaces. They are linked and there are overlaps between the different factors and are used to better understand urban spaces.

Character and Image. Successful spaces, streets, towns and cities tend to have some characteristics in common, and one of these principles than creates good urban design is a place with its own identity. Character in landscape and townscape is promoted by reinforcing and responding to the local distinctive patterns of culture, landscape and development. This sense of identity and character is due to the positive features of a place and people's contribution to its special character. Places which we know as being distinctive grew naturally to the local circumstances, were distinctive is ignored new development usually follows the latest fashions in design or corporate identities in design (DETR, 2000). In many cities and towns, there is a scope for strengthening existing identity of the area by linking it to a particular activity or mix, such as a marketplace, or by developing new areas with special character. These character areas reinforce the local identity and can help in raising the profile of a certain place, and also as a 
marketing tool. These may also relate to predominant uses, ethnic composition, historic associations or focal buildings, an example such as Chinatown (Yeang, 2000).

Diversity and Adaptability. Public spaces are places for everyone, for different ages, cultures, abilities and for a variety of different uses. Uses should be allocated appropriately with regard to their scale, accessibility, context, geographic characteristics and location of the space they will exist in. Design of the urban space should be simple and uncluttered to accommodate vending at different times since it is usually practiced optionally and irregularly (Huang et al., 2019). Since there has been more focus on cars and less on pedestrian's quality of life and vitality of the urban public space has been decreasing (Hammond and Musselwhite, 2013). Street markets have been developed in many countries as a place for people to socialize; it creates a vital public space and allows for better contact between rich and poor (Oranratmanee and Sachakul, 2014). These should have a diversity of activities, uses and behavior such as events and festivities, walking, shopping, relaxing and conversation with others. Social interaction takes place in public realm and associated semi-public spaces; for example, the sidewalk café, the shop frontage, the street vendor and the market square. Moreover, most people like to linger if there is protection from the weather and a comfortable place to sit (Jalaladdini and Oktay, 2012).

Location and Accessibility. Finding an optimal sidewalk system is very difficult and varies on a lot of factors which must be taken into consideration; the different uses and how long a space is needed for each use. It is mostly shared between a variety uses and it changes on different days and times of the day (Shehayeb and Abdelhalim, 2011). The two main factors in accessibility are visual accessibility which enables people to see a space and to know what is taking place there, and physical accessibility which enables people to enter and use the functions taking place in the space. Sidewalks should be designed to accommodate the widest 
range of users; all ages and also those with a wide range of mental and physical abilities. Access to the site is key; there should be adequate public transport and also access by car and parking for some visitors (Jalaladdini and Oktay, 2012). Also, the assortment of the vending booths, ambience of the marketplace, and the enjoyment of walking around make the buyers stay longer in the streets (Hammond and Musselwhite, 2013). The urban space should be inevitable and must attract people to come and use the facilities. This also leads to equitable environments shared by all sections of the society equally, and without diminishing the welfare of some groups. Equity creates a socially balanced and safe, the different levels of the social structure will interact without conflict and leads to vital public realm (Carmona et al., 2003).

Safety and Comfort. A key to success of a space is that it is comfortable and is perceived as safe, clean and with availability of places to sit. It is important to create a safe road network for people where there is access to emergency vehicles and prevent vehicle crashes through the design of sidewalks mainly. Adding a mix of uses such as residential especially in a commercial area, raises the chance of the area being populated after the regular opening hours. (Bloomberg et al., 2013). Moreover, a study by Yatmo (2009) suggests that street vendors presence at nighttime increases safety than at daytime, this is since safety is often more associated with nighttime (Hanyu, 1997; Nasar and Jones, 1997). This means that presence of street vendors at nighttime is desired and contributes positively to urban safety, since it occupies abandoned spaces and makes the space more alive and filled with activities. This could in turn legalize a policy for street vending at nighttime, especially in places that are underutilized at night, such as certain unoccupied streets, wastelands and parking lots (Yatmo, 2008). Cities are obligated to offer people good conditions for them to walk, watch, stand, sit, play, exercise, talk and listen. These are basic human activities that take place under good conditions and will be able to take place and unfold in all possible combinations (Gehl, 2010). 
Spatial Properties. In order to accommodate the dynamic nature of street vendors it will be difficult to provide fixed zones for their trading in the streets, because there won't be enough space to accommodate them. It is also difficult to create a solution that will work for all urban contexts, though there are some solutions that can reduce any tensions created. There are some recommendations for planning for day to night layering of the spaces, or even different days to accommodate various alternatives (Yatmo, 2009). Some guidelines suggest that only a $4 \mathrm{~m}$ wide pavement can accommodate vending, with or without fixed structures (Mahadevia et.al, 2014). In other cases, in New York City, vendors must always maintain a $2.4 \mathrm{~m}$ ( 8 foot) clear path, and second, vendors must not restrict access to adjacent buildings, not obstruct police and fire services, and not block display windows, signs, and street furniture (Browne et.al, 2012). In Vietnam, they sometimes paint lines on the pavement to apportion space between pedestrian throughways, sidewalk vending and parking (Barthelmes, 2012). Moreover, stalls should be coordinating to ensure market's quality is good overall, it should also be consistent to the area's character. Surfaces should be in good condition so they are practical for all users, also streets should be closed at high trading hours and at high traffic (Westminster Act, 1999).

Amenities and Maintenance. Innovative spatial forms in street-based trading are important to provide opportunities and increase the experimental aspects of shopping for a range of consumers. These spatial forms that should be regarded are the assortment of the vendor stalls, the space assigned for them, natural ambiance of tree grooves and parking space (Bloomberg et al., 2013). There are also some utilities and services that need to be provided for both street vendors and the customers, such as clean toilets, washroom and drinking water. Vendors also need shelter and shade to shelter them from weather factors; they also need storage space and waste collection facilities. It is essential to ensure that street vending does not cause unsanitary conditions and overcrowding in the public space. Moreover, the urban scene in the public's general preference is strongly related to maintenance and orderliness of street vendors. The 
street vendors must not arrange their goods in an improper or irregular manner on the streets. They must also maintain and keep their objects and goods in proper condition, without causing any dirt or waste (Yatmo, 2008). Moreover, toilet and washing/preparing facilities should be provided for traders and the public, also each stall should have an adequate rubbish disposal area, and storage were possible. Parking should be provided mainly for traders to handle their goods easily (Westminster Act, 1999).

\section{Data and Methods}

The study is based on analysis of a single case study, which consisted of observations and interviews in order to understand people's perception and opinion of street vending in streets of London. Users of the city evaluate image of the city, they are who 'read' the existing elements of the city and either perceive the environments positively or negatively (Nasar, 1998). Therefore, studying the users' evaluation of street vending will reveal the extent to which they like or dislike the existence of street vendors. The study was undertaken during the month of August 2019. Portobello Road and Golborne Road in the Royal Borough of Kensington and Chelsea were chosen due to having the largest number of street vendors in the area and are also filled with different uses. Their settings and uses changes during the week, vendors and market stalls are not always present all days of the week, and this is important to access how they affect the urban setting during their presence. Data was collected and analyzed through multiple methods. Data was collected from previous researches on street vendors and streets in general, to create a criterion to help in evaluating the current situation of street vendors in Portobello and Golborne Road. The criteria used to evaluate included character and image; diversity and adaptability; location and accessibility; safety; spatial properties; amenities and maintenance. Observation of the area took place at different times of day and on different days throughout the whole week. The street vendors were observed in order to know the following; different products they sell, how they affected their surroundings, whether they 
are mobile or static in a certain place and which part of the street or sidewalk do they occupy.

Changes in the market, how people were using it and areas of main social interaction were documented throughout the study period. The study also consisted of individual semistructured interviews with 14 vendors, users and shop keepers of the streets, which exist in the same area as the location of the street vendors and use the street, to assess their opinion on the street vending, advantages and disadvantages of their existence in the area.

\subsection{Background}

Portobello and Golborne Road markets, located in west London exists since 1860s, are one of the most famous markets in the world specializing in selling antiques. It is estimated that every Friday and Saturday almost 100,000 visitors visit the Portobello Road. All kinds of products are sold there from antiques, to fruits and vegetables. Despite the fact that the of the high footfall and its fame, many believe that the market is under threat with the rising rent driving some local stalls to close (Brooker, 2014). Flea markets and antiques attract very high footfall of mainly tourists on Friday and Saturday, the rest of the week are primarily serving locals. The fact that the footfall is only high on certain days of the week makes it less attractive to multiple retailers (RBKC, 2010). Street trading in Portobello and Golborne Road is managed through the London Local Authority Act, the market team mixes the stalls to help both locals and tourists throughout the mile-long market, this is done through Portobello more specifically (LEAP, 2017). On Fridays and Saturdays, the street market in Portobello Road is divided into three main section: a flea market in the north; new goods and fruit and vegetables in the center; antiques and bric-a-brac in the south. During the rest of the week only the central area of the market is operating. Golborne Road Market to the north, operate all days of the week except for Sundays and Thursday afternoons (RBKC, 2010). From in-depth fieldwork, it was apparent that street vending in the two streets studied is a vital part of the area especially in Portobello Road. 


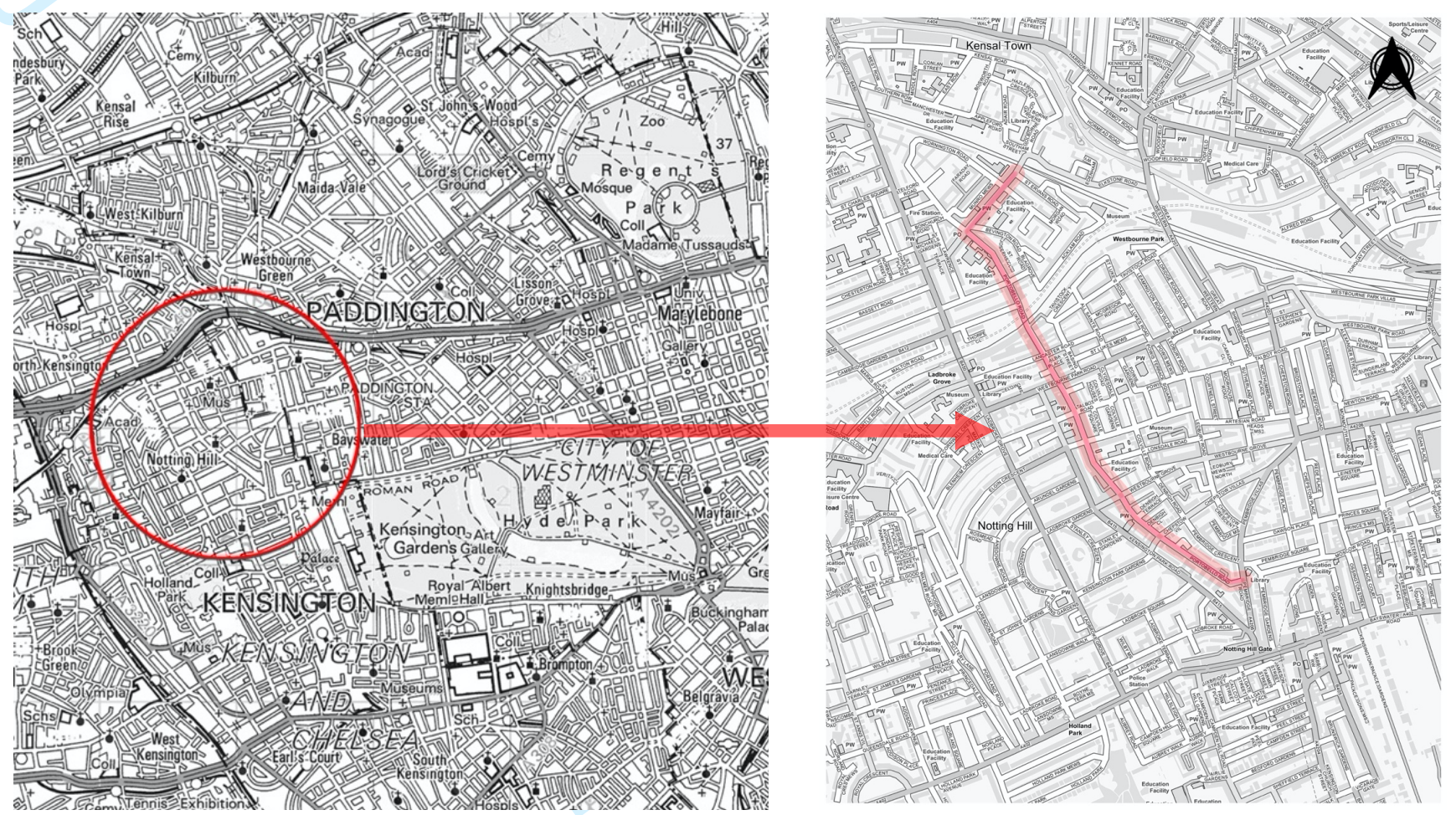

Figure 1: Map showing the location of the study area with a central location (source: digimaps)

\section{Findings and Analysis}

\subsection{Zoomed in Spatial Configurations}

The study area was divided into four different sectors; three sectors along Portobello road and one sector at the northern end of Portobello road and its intersection with Golborne road. The areas were visited on all days of the week, including a Saturday on which most parts in the study area are closed and pedestrianized. The different sectors were observed to note the areas were vendors are located, spillover from adjacent buildings occurs, areas of social interaction and community behavior. These sectors were developed into two maps mainly on a Saturday (busiest day) and on a weekday to document the changes which occur in both activity settings and behavior, and to see street vendors' effect on the urban setting. Sector 1 is located on the Southern end of Portobello Road and it is where the pitches for the vendors start to appear on one side of the road. The road is defined by low-rise commercial buildings on the west side and a gated residential area on the east. Size of the pitches at this part of the road is the smallest 
with an area of about $2.7 \mathrm{~m}^{2}$. In this part of the road most of the ground floor uses which are commercial sell new clothing and accessories, with a couple of food retail shops, and some are empty. The vendors in this sector mostly sell antiques or new clothes and accessories as well.

Sector 2 is slightly different from sector 1 , as it contains more street food, fruits and vegetables vendors, and more ground floor food which attracts more people to this area. The road is defined by low-rise commercial buildings on both sides, there is a cinema and 2 supermarkets, and the rest are mainly cafes, restaurant and shops. The vendors are also located on the eastern side of the road occupying part of the street, here the pitch area where they are allowed to vend is larger than the ones in Sector 1, with an area of almost $6 \mathrm{~m}^{2}$. The wider sidewalk on the right allows for more space for pedestrians to walk and see what is sold by both vendors and the shops. Since there is a lot of food retail in this part there is more staying and sitting in this part of the road. The eastern side of the road experiences more pedestrian traffic than the western side, since vendors are allocated on the eastern side and more activities can be seen and done. There are also several food outlets in this sector, and famous food and retail outlets found in most high streets, so they attract people. This leads to people seeking for areas to stay and sit, ending up sitting on the floor on side streets where it is less crowded. Vendors mainly display their products towards the sidewalk, but in some cases, they serve people on both sides. Usually on weekdays the vendors that appear on other weekdays are usually the ones selling fruits and vegetables or clothes.

Sector 3 has several different areas with variety of products sold, the southern part is similar to the vending styles with pitches on both sides of the road mainly selling new clothes. Area of the vending pitch in the northern and southern parts of this sector is around $6 \mathrm{~m}^{2}$, the rest of the vendors in this sector don't have a numbered pitch with a specific are to undergo their vending activities in. Then mid part of the sector consists of stalls selling street food on the eastern part, 
the stalls are organized next to one another and back to back in an empty plot northern to the Westway Flyover. The part under the Westway Flyover is utilized as a seating area for the food stalls on Saturdays. On the opposite side of the food vendors, there are stalls selling mainly antiques and vintage clothing and accessories. They are located under the Flyover in a large empty space and along a path under the Flyover, and under a white tent towards the northern part. A lot of areas under the flyover are utilized for vending, because it is partially protecting people and goods being sold from climate conditions. The last part of the sector towards the north goes back again to the street pitches were vendors are located only on the eastern side of the road. Usually visitors end their trip at this sector of the road and the rest of the road market has less footfall than the previous sectors, this can be seen especially on Saturdays.

Sector 4 is located at the end of Portobello road market and its intersection with Golborne and its market. The products sold in this sector are vintage and new clothes and accessories, antiques and a few food vendors. Vendors pitches are only found on the eastern side of Portobello road and on both sides in Golborne road, all at around $6 \mathrm{~m}^{2}$. In this sector, Portobello road part is mostly enclosed by a wall, with artwork, to separate the residential and other private uses from the road. This creates a continuous monotonous barrier along the road, at this sector the footfall even on Saturdays is much less than the rest of the road and other sectors. Also, on the busiest days the pitches are not all occupied by vendors in Portobello road. On the weekdays this sector is almost empty as there are not a lot of ground floor uses along this road especially the southern part. There are some extensions and spillover activities from the ground floor uses, mainly the cafes and restaurants but also not as crowded as the previous sectors. On days were vending is not taking place, Portobello road part is completely empty and in Golborne road some cars are parked were the vendors exist. Portobello road part of this sector is also closed on Saturdays, however Golborne road is never closed and pedestrianized at any days of the 
week. Also, what has been noticed is that most of the users of Golborne street are locals and residents of the area and not tourists especially on weekdays and not Saturdays.

On Saturday, the busiest day, all sectors in Portobello Road are closed except for some intersections and crossroads, all other days of the week there are vehicle access within the road. The road gets very busy on Saturday at noon people can barely walk through the crowds, especially in front of the vendors and in front of the shops. Most of the shops have outdoor displays and extensions on the sidewalk, this crowds the sidewalk even more with people standing to look at the goods being displayed. People end up walking in the streets because it is difficult to pass the people standing and shopping. The road was observed on different Saturdays, one was sunny and the other cloudy and raining, the weather affected the footfall and the amount of people in the road dramatically, it was busier on the sunny day. On other weekdays, and even Friday that is regarded second busiest day, the road is not closed and pedestrianized on these days and cars are sometimes parked at the location of the vendors' pitches. At some points the sidewalks get crowded and people are forced to walk in the street but must be cautious of vehicles passing by. The crosswalks and intersection where there are usually high levels of pedestrians is almost empty, even the large area in front of the café is unoccupied as well. It is clear and apparent that vendors have a huge effect on the number of visitors to this area, they increase dramatically when there are vendors. Also, since there aren't a lot of ground floor activities in these areas especially the mid-section of Sector 3 it becomes almost empty. Even cafes and restaurants nearby are almost empty, they still use the sidewalk for extension, but footfall is very low. 

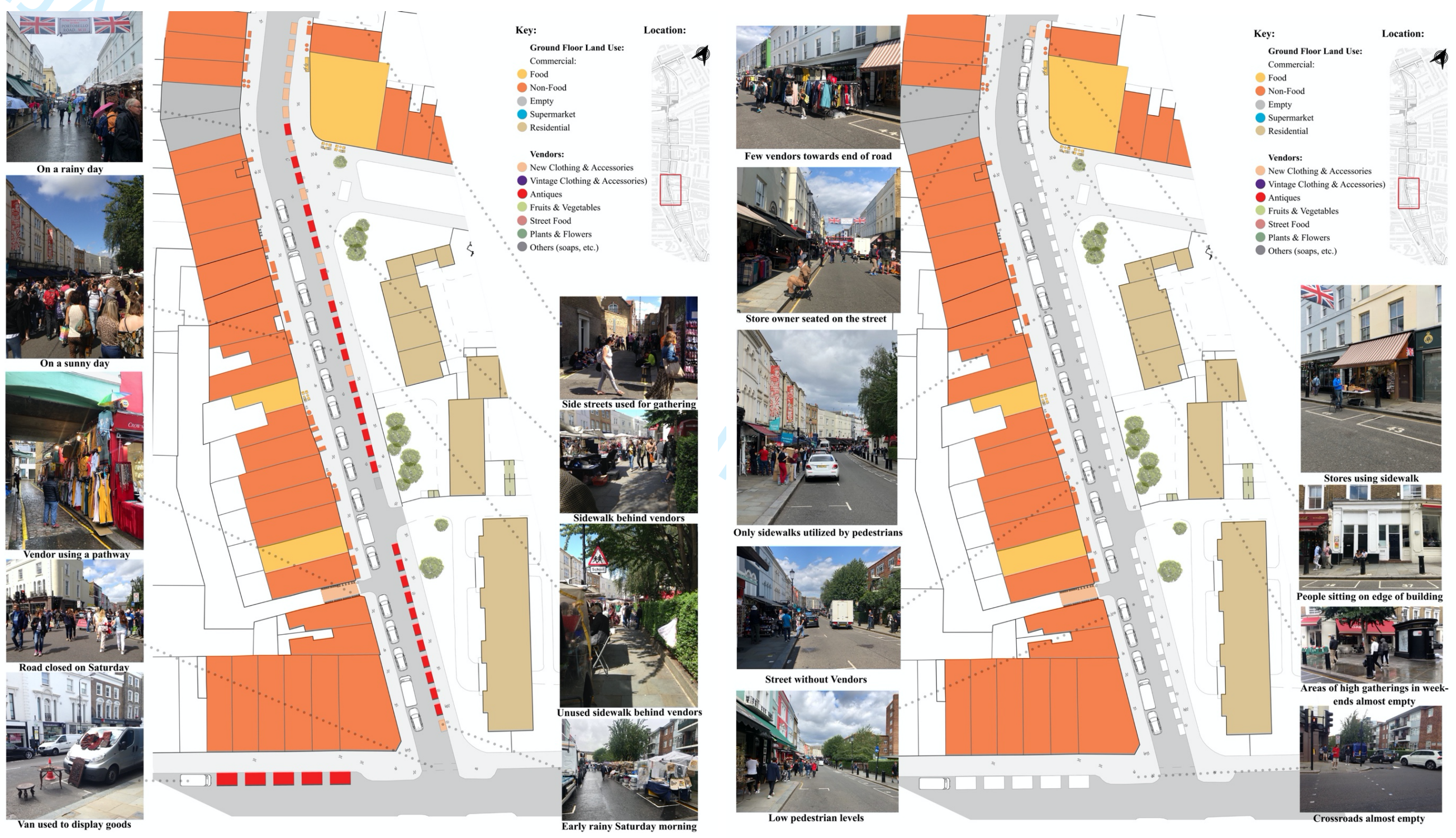

Figure 2: (left) Sector 1 on Saturdays, (right) Sector 1 on Weekdays (source: author)

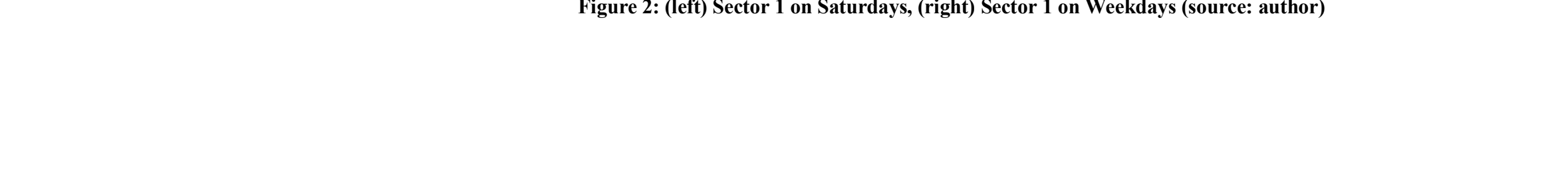



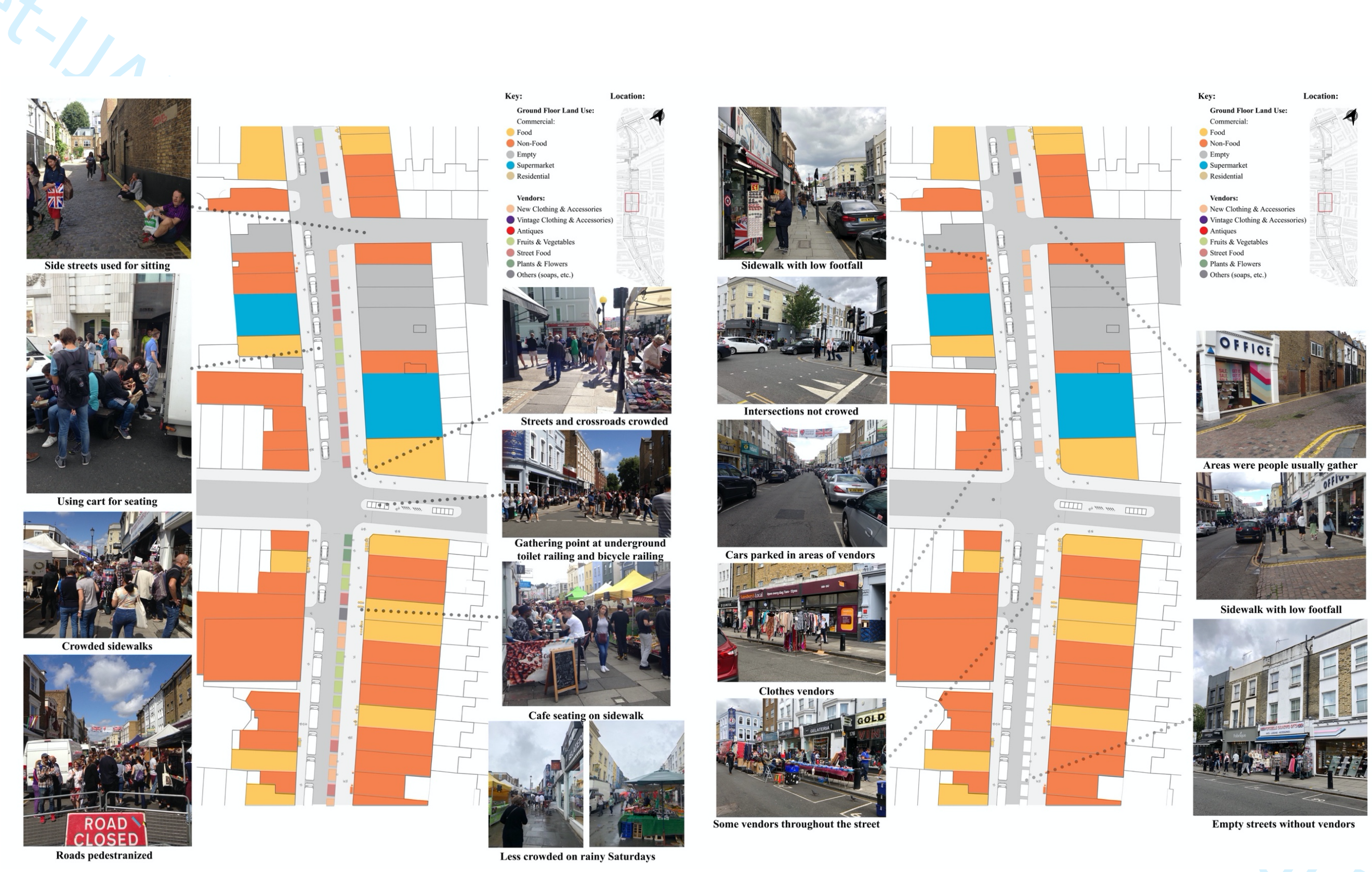

Figure 3: (left) Sector 2 on Saturdays, (right) Sector 2 on Weekdays (source: author) 

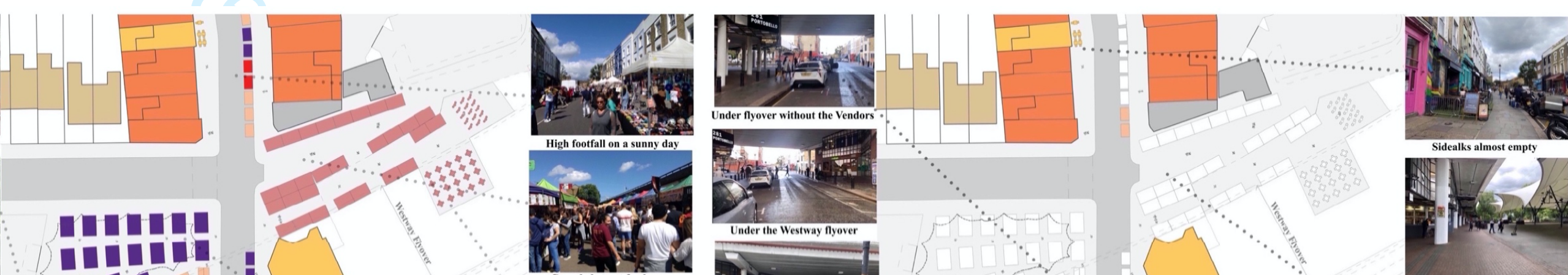

(10) 2$)^{2}$ 19
$20^{\circ}$
21
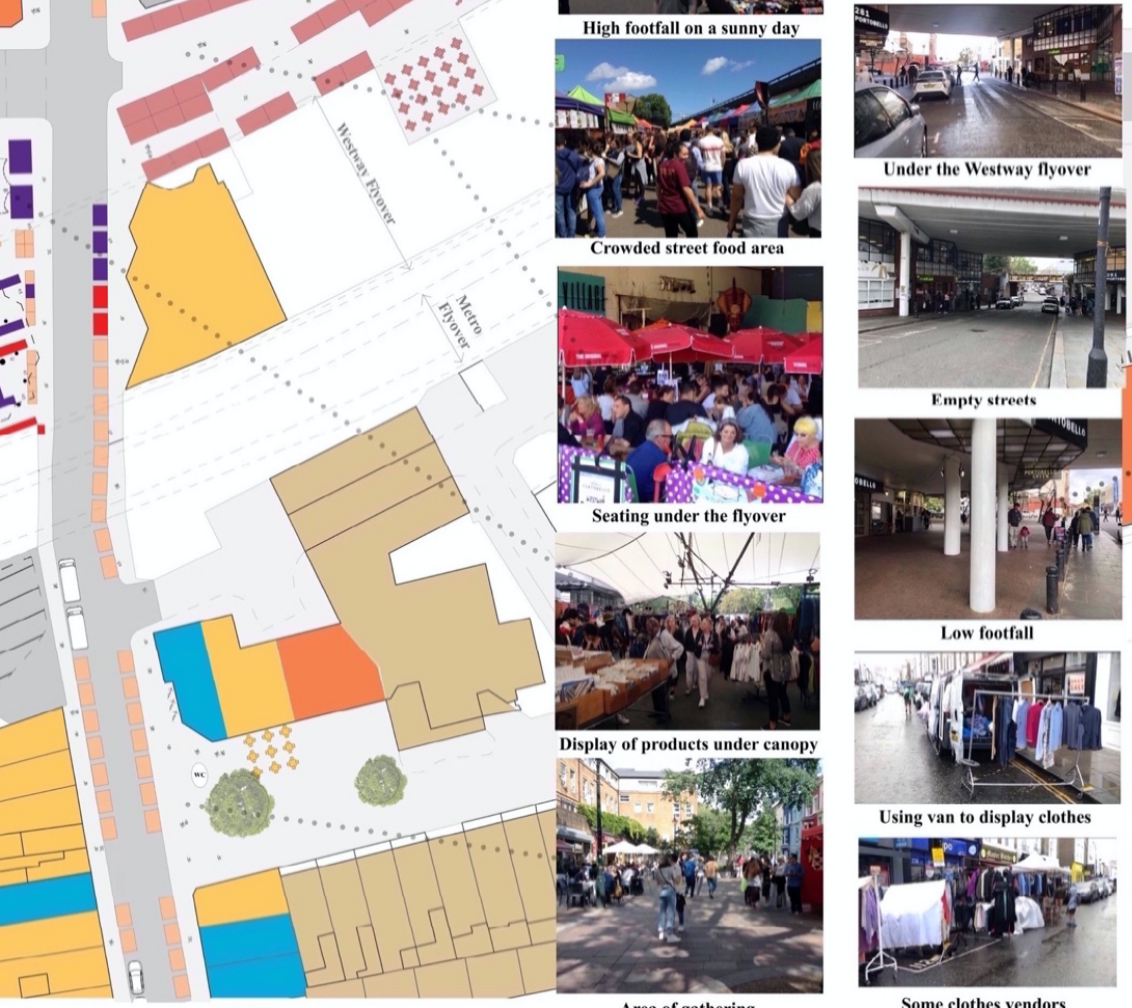

int

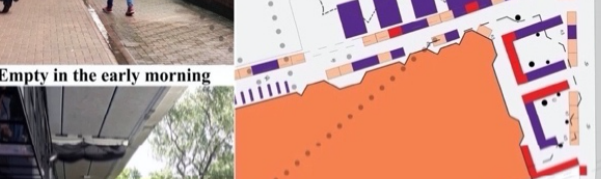

$$
\begin{aligned}
& 25 \\
& 25 \\
& 2 \\
& 2 \\
& 29 \\
& 30
\end{aligned}
$$

i.
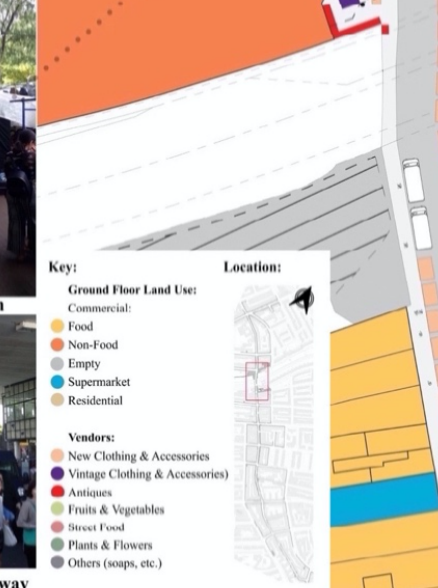

alyover

Area of gattering
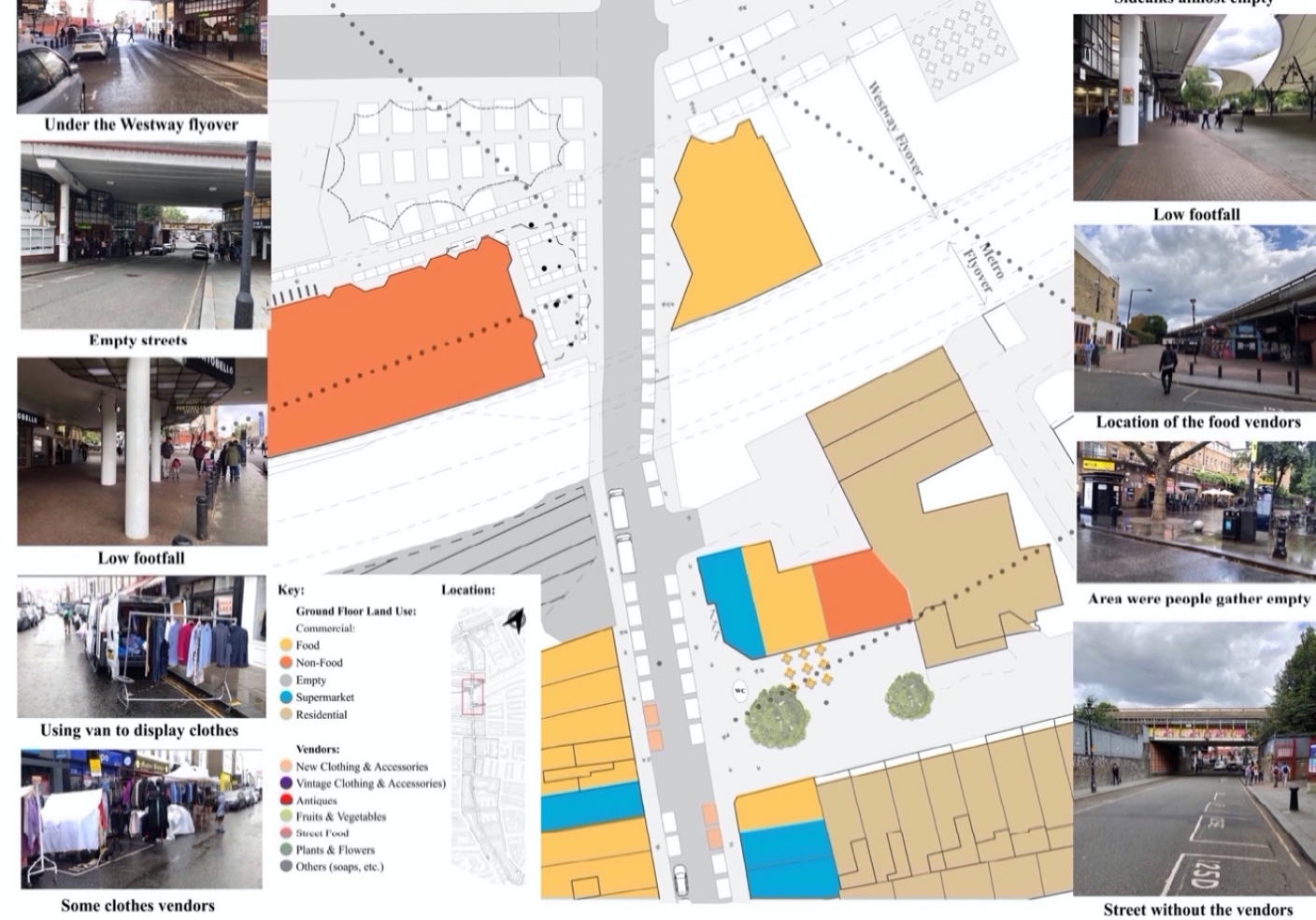

Figure 4: (left) Sector 3 on Saturdays, (right) Sector 3 on Weekdays (source: author) 


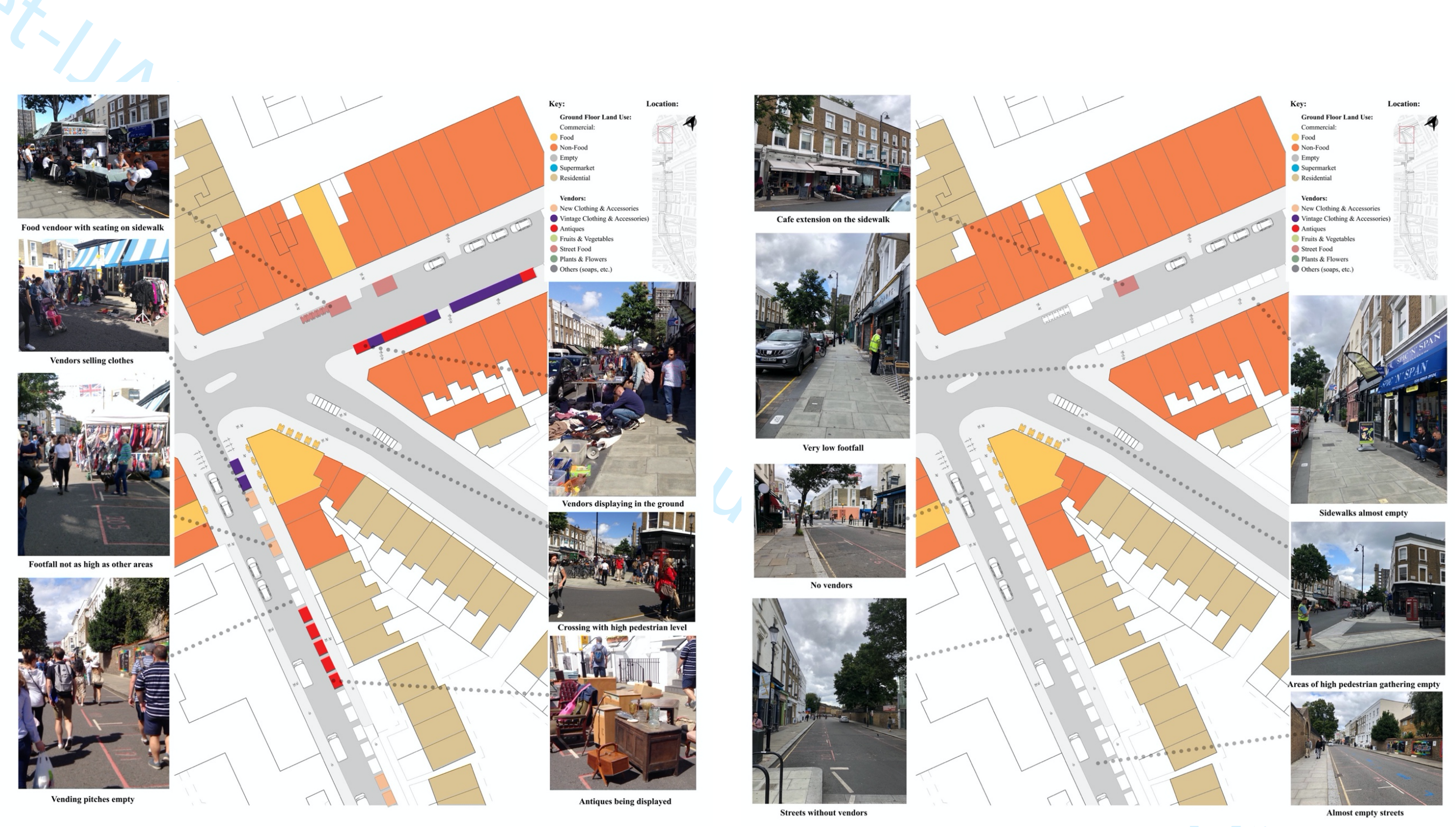

Figure 5: (left) Sector 4 on Saturdays, (right) Sector 4 on Weekdays (source: author) 


\subsection{Perceptions of Vendors, Shop Keepers and Users}

Interview responses indicated that users of the streets were mostly satisfied with the products the vendors had to offer. One of the interviewees claimed that the main reason they came to the area was because it was a well-known and famous tourist spot. It was recommended by many people to them and that they would find affordable and unique souvenirs they can take back home. Interviewees which were tourists, also stated that they would probably only come once to this area during their visit to London. However, locals said they usually come twice a month or every week, but they mainly shop at the fruits and vegetables vendors or for food. One of the local users of the area confirmed that one of the good things about street vendors is that they offer products that compliment with the types of products present inside the shops. On the other hand, interviewees were unsatisfied by a couple of things especially when the area is crowded, is that there is no enough space for everyone on the sidewalk and they can't see the products being sold well. Also, stated that presence of cars was unnecessary in the roads even when it is pedestrianized and is some areas the vendors are too close to one another. Moreover, they noted that if there is food being sold by vendors there should be areas where people can sit and enjoy their food. The vendors interviewed stated that they are mainly present on Fridays and Saturdays, and that it was not worth coming and setting up their goods on other days since there weren't a lot of visitors. One vendor complained about parking space and on busy days they usually needed to get more goods, and sometimes the road is closed, and it is extremely difficult to carry goods through the crowds. Other than that, they were generally satisfied with the street market. They also stated that when the weather is nice and sunny more visitors come to the area. Moreover, shop keepers that were interviewed mentioned that they were open on all days of the week, but also confirmed that the vendors and street market does attract more people to the area. One of the shop keepers even had a rented pitch close by his shop and noted that it is easier to sell from the pitch on the street during busy days 
than from the shop. Their only concern was that some vendors and their customers left rubbish on the street and sidewalks, but it was usually removed later on. One of the shop keepers was suggesting that the market street vendors were present on more days of the week or longer hours but was not sure if there would be enough customers to be served.

\subsection{Analysis of Street Vending in Portobello and Golborne Road}

Through extensive review of relevant literature, the six factors were found to have an important effect on street vending, markets and everyday successful urban spaces. They are used to analyze street vending in Portobello and Golborne Road.

Character and Image. Portobello and Golborne roads are well known for street markets and especially the antiques, it attracts a lot of crowds. Southern end of Portobello road is enclosed by its famous multicolored Victorian terraces, which creates a wonderful backdrop to the street market. They also attract many tourists as they have been featured in movies, and people visit to take pictures. As you move further north the buildings lose this unique character of colorful façades and become more monotonous. Even the ground floor shop within those buildings can be found in any high-street and are no different than them. Similar to the rest of the road and Golborne road they don't have anything special or a unique kind of architecture, nonetheless they've always been known for their markets. The market plays a strong role in determining the image of these 2 roads and also attracts a lot of locals and tourists to the area.

Diversity and Adaptability. Being a street market, the most dominant types of activities occurring in the study are is buying and selling. There are a wide variety of products being sold in both the shops or by the street vendors, from vegetables and fruits to used furniture. The vendors present in the streets change every day and they even sometimes change their locations, since they can easily set up and pack the goods they sell. Moreover, the market and shops attract a wide variety of users from different backgrounds, and even tourists from all 
around the world. Street food sold there is from all around the world, and there are areas were people can sit, stay and socialize with one another, and enjoy the food. Vending is present on different days and different times as well, but usually ends at around $5 \mathrm{pm}$ and the area later becomes less crowded and there aren't any night activities. Saturday which is the busiest day Portobello road closes to allow for the greater number of visitors that come to the area and usually that is the only day in the week were all vendors are present. Additionally, a lot of ground floor shops have extensions whether its cafes, restaurants or clothing and accessories shops and this allows for activities to occur along the edge of the road.

Location and Accessibility. It is observed that the majority of visitors arrive from the southern side of Portobello road usually by public transportation arriving at Notting Hill Gate and from there signs and maps help navigate people to the market. It is also noticed that on days when the road is busy this area as well has higher footfall. The street vendors appear further north with intersection with Westbourne Grove up until Golborne road. There aren't any other adjacent areas which attract high pedestrian volumes next to Portobello road, and it is clear that even areas adjacent are utilized due to its presence near those areas. It was noticed that accessibility to Portobello road is not clear, but people usually follow the crowds or use the directions and maps that are present along the road. Accessibility to Golborne on the other hand is difficult and it is observed that a few people actually reach to the northern part of Portobello to get there. This mainly occurs when the vendors are present, and they help in visually connecting the two roads with one another. Furthermore, the location of vendors in this area is seen as appropriate, since the roads are not that busy with vehicles and vendors can be present without any issues most of the time. On Saturday's Portobello road is pedestrianized except for the main intersections, to allow for people to walk and use the roads freely and move from one sidewalk to the other. However, it is very difficult for the vendors or shops to get any goods from storage or from their vehicles especially on busy days since the road is filled with 
pedestrians. Finally, parking spaces in the area are very limited and there are usually vans parked in the road with vendor's goods, which lessens the areas where people can walk.

Safety and Comfort. Presence of the street vendors in the area increases footfall and without them some areas are completely vacant, they contribute to safety of the place. Also, since it occupies many of the unoccupied areas under the flyovers towards the northern part of Portobello road. They also allow for increase of social interaction between people. There is a mix of uses in the area since most of the neighboring areas are residential, so this leads to more people using the streets at different times of day. However, the number of incidents near Portobello road are higher than in adjacent parts (source: data.police.uk), this could be due to the fact that there are more people present in this area in compared to other areas. When the roads get really crowded and busy on Saturdays the sidewalks and streets become uncomfortable and difficult to walk in some parts of the road. On other days when the road is not pedestrianized, it becomes unsafe for pedestrians to cross the road since vehicles are present. Issues also noticed in the study area is that there aren't enough spaces for people to stay and sit, and people end up sitting on the floor or lean on any edge or object besides them. Furthermore, on days when it is raining there isn't a lot of protected areas for pedestrians to stay at, and usually enter shops or find any places for shelter.

Spatial Properties. Street and sidewalk width changes from the three different sections. Sidewalk spillover activities change as well however on Saturdays it gets very busy and is difficult to pass by. Portobello road has fixed zones for trading and number pitches were vendors have to abide to certain guidelines and maximum setup areas. The pitches are numbered, some for the vendors to sell goods and also ones for bins and ones that has 'keep clear' on it for emergency vehicles. In some locations even the parking lots are numbered as they are sometimes used by vendors to park their vans where they store their goods. There are 
three main spatial configuration of Portobello and Golborne road as seen in Figures 6, 7 and 8.

It was also noticed that well-known coffee shops and restaurants are located strategically at corners of the street not only to have a larger sidewalk area but also helps in attracting people to continue along the road and explore the rest of it.

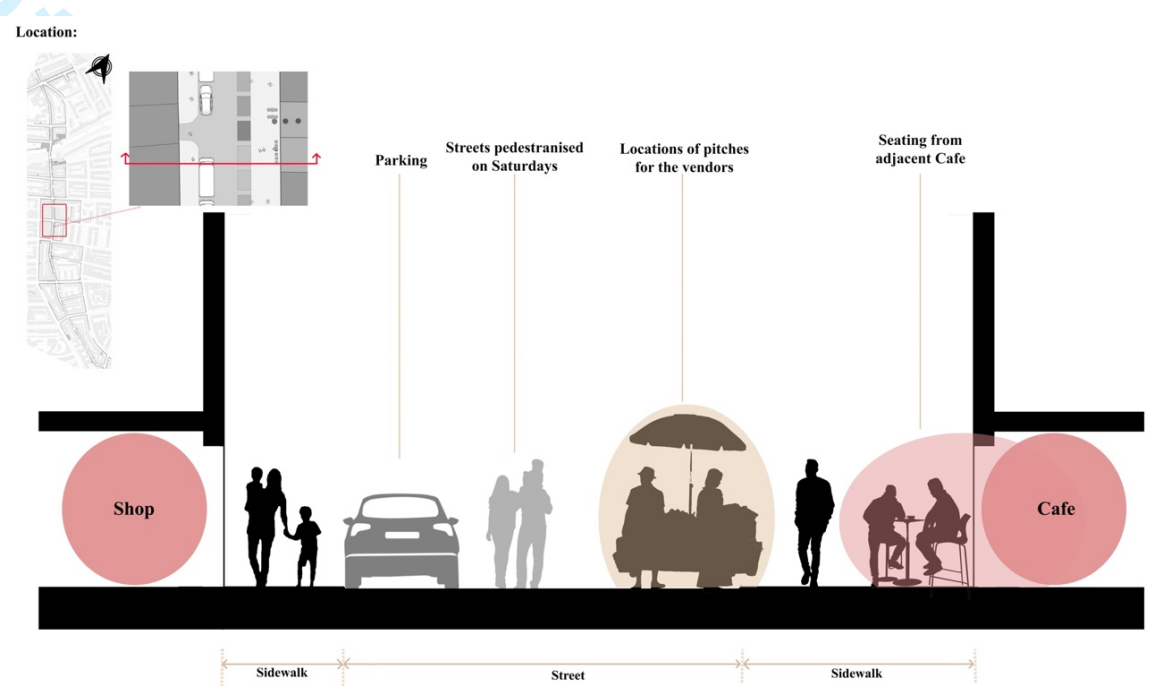

Figure 6: The street at towards the southern side of Portobello Road 12m in width (source: author)

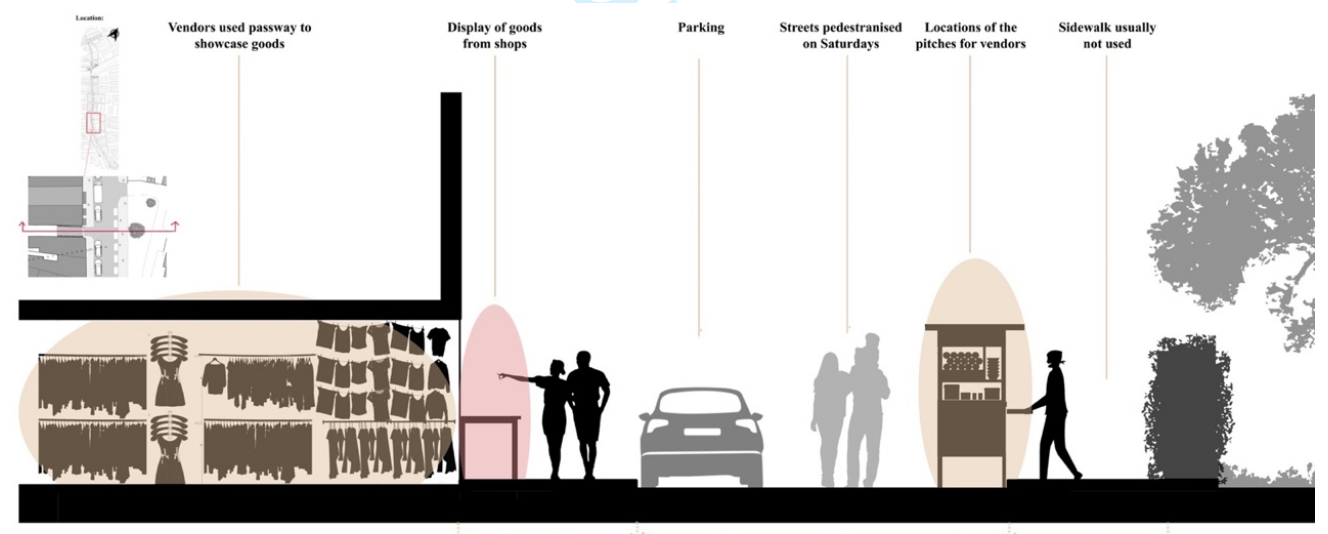

Figure 7: The street at towards the middle of Portobello Road 16m in width (source: author)

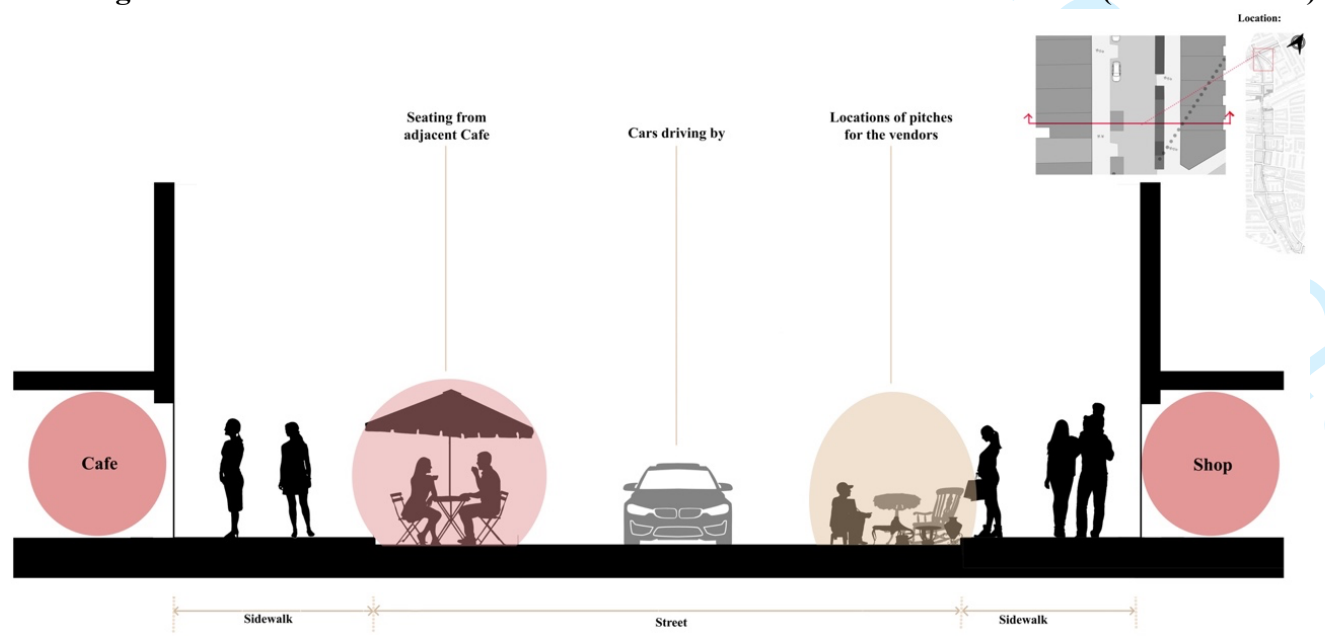

Figure 8: The street at Golborne Road 20m in width (source: author) 
Amenities and Maintenance. Throughout the road there are several toilets provided for the public, also several plots for bins, though some vendors and shops put their rubbish on the sidewalk. Since the roads are quit narrow some vendors use the parking spots opposite to them to store the goods they need for the days. Surfacing and pavement is in good condition throughout the road, some areas are under maintenance. When the road is closed on Saturdays and it is pedestrianized it is quite difficult for vendors to get their goods from the storage area since it is very crowded.

\section{Conclusions}

Street vending takes up an important part of markets, as a result it also plays a vital role in creating lively and successful streets, sidewalks and urban places in general. They inevitably have many benefits for vitality and liveliness of the urban environment; however, they also cause some difficulties and problems for everyday users of the space. After investigation the following are benefits of street vending; they create social connectivity between users themselves and vendors. It creates an urban space which accommodates several different uses and users from all backgrounds. Street vendors are an important part of the urban life in the area studied especially on Fridays and Saturdays. They offer products, sights and trigger different senses for the users and customers buying from them. Also, vending pitches and plots are well organized and numbered throughout Portobello Road to keep order and allow all vendor equal spaces. On the other hand, some of the problems caused was mainly congestion, forcing pedestrians to walk in the streets and poor waste disposal. This could be solved by removing unnecessary vehicles especially when Portobello Road is pedestrianized. Some of the vending is not protected well from environmental factors and simply placed on the floor, which would be quite difficult in winter or heavy rainfall. Some disposal and trash were found on pavement and sidewalk which caused difficulties in walkability, these should be relocated. Additionally, there weren't any seating areas in most of the road, people had to sit on fences 
or on the bike storage area, also some people sat on the floor in some quite side roads. Vendors especially ones selling food should dedicate a close by seating area especially on busy days, that could be later removed. To conclude, a city without a marketplace lacks sense of place and a platform for gathering and socializing. Street vending is not easy to regulate due to its mobile nature and depending on the levels of customers and visitors. Though, vendors in Portobello Road specifically are found successful and attract large numbers of visitors.

Moreover, due to the limited time frame of the research, not all the points and ideas of the topic could be studied. Since street vending exists in many parts of London, more locations could be studied and analyzed to try to precisely define the benefits and problems caused by this activity. Since the study was only undertaken during the summer period in August, it is also important to carry more observations and research throughout the entire year, since weather affects the number of people. Through a larger study we could draw a demographic trend that accumulates the whole region and incorporate geographic information systems. Also, a larger number of interviews could take place with addition to questionnaires, in order to take the opinion of a larger population on the acceptance or rejection of street vendors. Solutions to improve street vending, maximize their benefits in creating a vital public space and decrease the problems they create could be modified in the urban space and experimented to measure satisfaction of the urban dwellers. It is anticipated that the ideas presented in this research motivates us to further improve and develop public life on streets.

\section{References}

- Appleyard, D. (1981), Livable Streets, University of California Press, Berkeley.

- Barthelmes, L. (2012), "Peasants or Peddlers? Mobile Street Vendors in Hanoi, Vietnam", available at: https://www.eth.mpg.de/3394593/projekt (accessed 20 June 2019).

- Bloomberg, M.R., Burden, A., Burney, D., Farley, T. and Sadik-Khan, J. (2013), “Active Design: Shaping the sidewalk experience", City of New York: Report from City Council, New York. 
- Bostic, R.W., Kim, A.M. and Valenzuela Jr, A. (2016), "Guest Editors' Introduction: Contesting the Streets: Vending and Public Space in Global Cities", Cityscape, Vol.18 No.1, pp.3-10.

- Bromley, R. (2000), "Street vending and public policy: a global review", International Journal of Sociology and Social Policy, Vol.20 No.1/2, pp.1-28.

- Brooker, N. (2014), "Market forces: the changing face of London's Portobello Road", available at: https://www.ft.com/content/026b5e98-af61-11e3-bea5-00144feab7de (accessed 20 June 2019).

- Browne, R., Joaquin, D., Keliiaa, J., Kirschling, K., McDowall, D., Rosenberg, S. B., et al., (2012), "New York City Street Vendors: Columbia University", available at: http://www.spacesofmigration.org/migration/wordpress/wpcontent/uploads/2017/05/StreetVendorReport_Final.pdf (accessed 20 June 2019).

- Carmona, M., Heath, T., Oc, T. and Tiesdell, S. (2010), Public Places - Urban Spaces: The Dimensions of Urban Design, Architectural Press, Oxford.

- Colin, L. (2018), "Street Vending from the Right to the City Approach: The Appropriation of Bhadra Plaza", Cabannes, Y., Douglass, M., and Padawangi, R. (Eds.), Cities in Asia by and for the People, Amsterdam University Press, Amsterdam, pp.259-282.

- Crawford, M. (1999), "Blurring the boundaries: public space and private life", Chase, J., Crawford, M. and Kaliski, J. (Eds.) Everyday Urbanism, The Monacelli Press, New York, pp.22-36.

- Creswell, T. (1996), In placelout of place: Geography, ideology, and transgression, University of Minnesota Press, Minneapolis.

- Cullen, G. (1971), The Concise Townscape, Architectural Press, London.

- Department of Environment, Transport and Regions (DETR) (2000), By design: Urban design in the planning system: Towards better practice, DETR, London.

- Gehl, J. (2010), Cities for people, Island press, Washington, DC.

- Gehl, J. (2011), Life between Buildings: Using Public Space, Island Press, Washington, DC.

- Gonzalez, S. and Waley, P. (2012), "Traditional retail markets: The new gentrification frontier?", Antipode, Vol.45 No.4, pp.965-983.

- Gvion, L. (2017), "Space, gentrification and traditional open-air markets: how do vendors in the Carmel market in Tel Aviv interpret changes?", Community, Work and Family, Vol.20 No.3, pp.346-365.

- Hammond, V. and Musselwhite, C. (2013), "The Attitudes, Perceptions and Concerns of Pedestrians and Vulnerable Road Users to Shared Space: A Case Study from the UK", Journal of Urban Design, Vol.18 No.1, pp.78-97.

- Hanyu, K. (1997), "Visual properties and affective appraisals in residential areas after dark", Journal of Environmental Psychology, Vol.17 No.4, 301-315.

- Hough, M. (1990), Out of Place: Restoring Identity to The Regional, Yale University Press, New Heaven and London

- Huang, G., Xue, D. and Wang, Y. (2019), "Governmentality and Spatial Strategies: Towards Formalization of Street Vendors in Guangzhou, China", International Journal of Urban and Regional Research, Vol.43 No.3, pp.442-459.

- Jacobs, J. (1961), The Death and Life of Great American Cities, Penguin Books, London.

- Jalaladdini, S. and Oktay, D. (2012), "Urban Public Spaces and Vitality: A Socio-Spatial Analysis in the Streets of Cypriot Towns", Social and Behavioral Sciences Vol.35, pp.664-674.

- London Economic Action Partnership (LEAP) (2017), Understanding London's Markets, Greater London Authority, London. 
- Pang, C. and Sterling, S. (2013), "From Fake Market to a Strong brand? The Silk Street Market in Beijing", Built Environment Vol.39 No.2, pp.224-235.

- Lynch, K. (1960), The Image of the City, MIT Press, Cambridge.

- Mahadevia, D., Brown, A., Vayas, S. and Patel, T. (2014), "Inclusive Design for Street Vendors in India", Centre for Urban Equity, CEPT University, Ahmedabad.

- Nasar, J. (1998), The Evaluative Image of the City, Sage Publications, Thousand Oaks, CA

- Nasar, J. and Jones, K. (1997), Landscape of fear and stress, Environment and Behavior, Vol.29 No.3, pp.291-323.

- Oranratmanee, R. and Sachakul, V. (2014), "Streets as Public Spaces in Southeast Asia: Case Studies of Thai Pedestrian Streets", Journal of Urban Design, Vol.19 No.2, pp.211229.

- RBKC (2010), "Core Strategy for the Royal Borough of Kensington and Chelsea with a Focus on North Kensington Development Plan Document" available at: https://www.rbkc.gov.uk/PDF/3\%20Core\%20Strategy\%20Section\%202a\%20(Chapters\%2019-28)-1.pdf (accessed 20 June 2019).

- Refaat, M. and Kafafy, N. (2014), "Approaches and Lessons for enhancing walkability in cities", International Journal of Education and Research, Vol.2 No.6, pp.301-322.

- Shehayeb, D. and Abdelhalim, K. (2011), "Maximising Use Value: Action Guide for Informal Areas", Deutsche Gesellschaft für Internationale Zusammenarbeit (GIZ).

- Southworth, M. (2005), "Reinventing Main Street: From Mall to Townscape Mall", Journal of Urban Design, Vol.10 No.2, pp.151-170.

- Spierings, B., Van Melik, R. and Van Aalst, I. (2016), "Parallel Lives on the Plaza: Young dutch Women of Turkish and Moroccan descent and Their Feelings of Comfort and Control on Rotterdam's Schouwburgplein", Space and Culture, Vol.19 No.2, pp.150-163.

- Ünlü-Yücesoy, E. (2013), "Constructing the Marketplace: A Socio-spatial Analysis of Past Marketplaces of Istanbul”, Built Environment, Vol.39 No.2, pp.190-202.

- Watson, V. (2009), "The planned city sweeps the poor away: Urban planning and 21st century urbanization", Progress in Planning, Vol.72 No.3, pp.151-193.

- Whyte, W.H. (1988), City: Rediscovering the Center, Doubleday, New York

- Yatmo, Y.A. (2008), "Street Vendors as 'Out of Place' Urban Elements", Journal of Urban Design, Vol.13 No.3, pp.387-402.

- Yatmo, Y.A. (2009), "Perception of street vendors as 'out of place' urban elements at daytime and nighttime", Journal of Environmental Psychology, Vol.29 No.4, pp.467-476.

- Yeang, L.D. (2000), Urban design compendium, English Partnerships/Housing Corporation, London.

- Zhong, L. and Tan, M. (2020), "Edge effect of streets in old residential areas in Chengdu, China", Open House International, Vol.45 No.3, pp.313-326. 


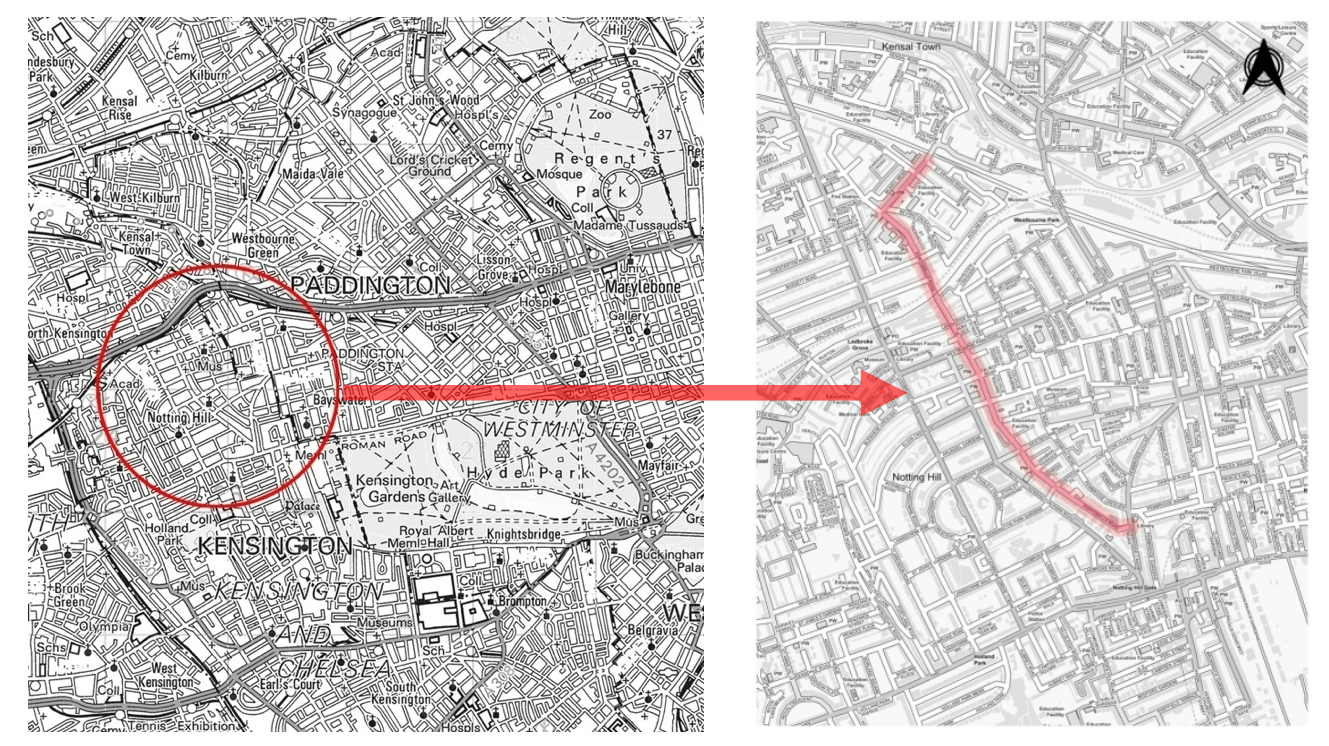




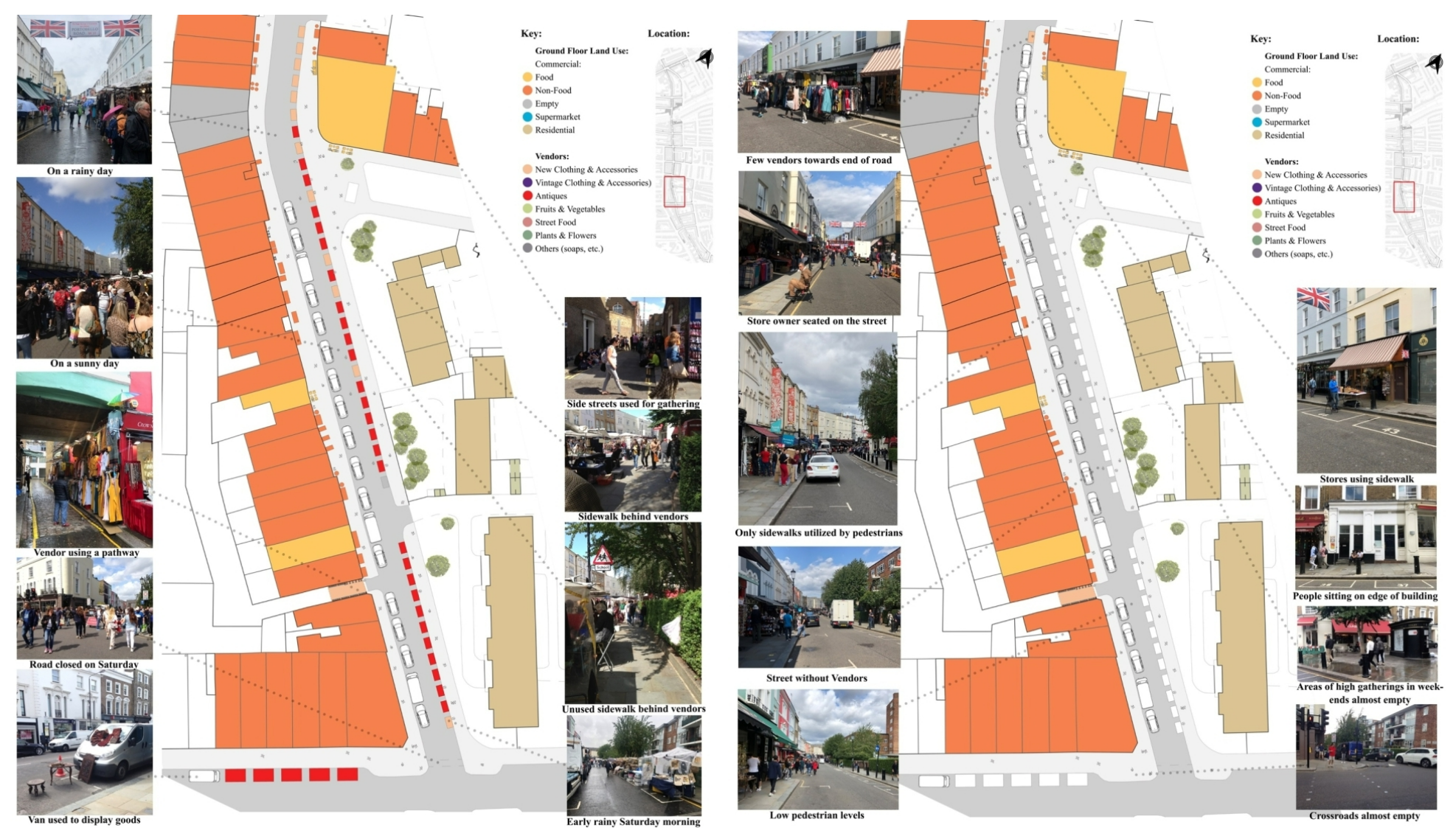



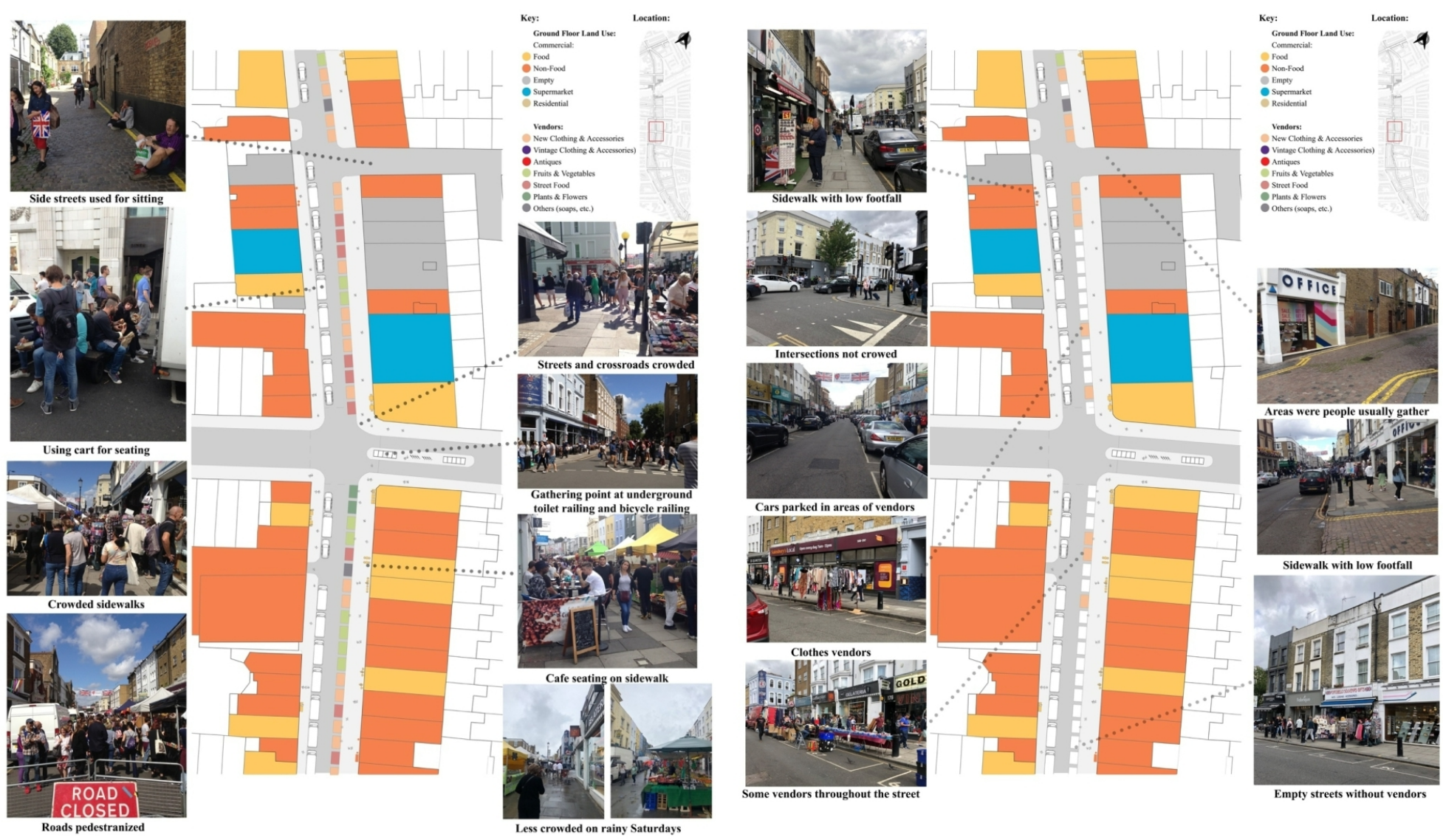


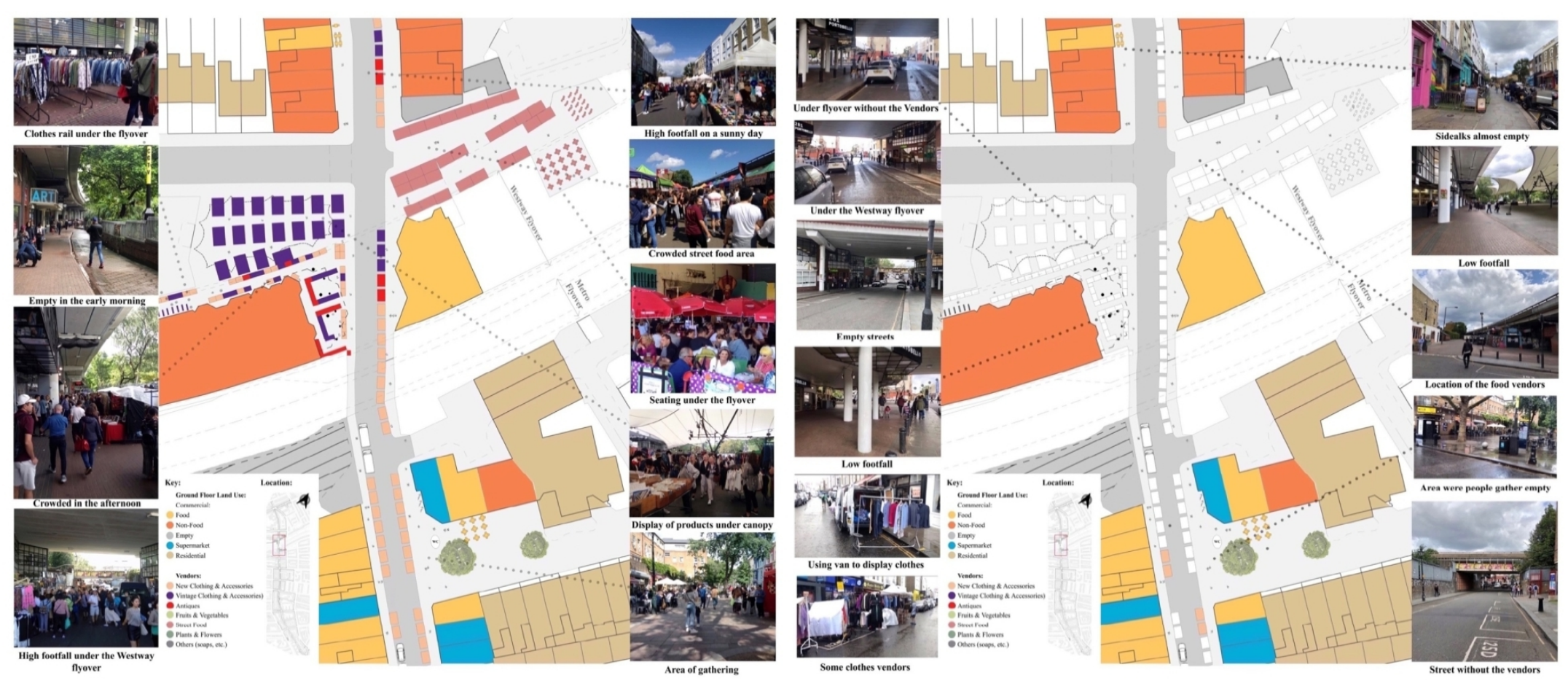



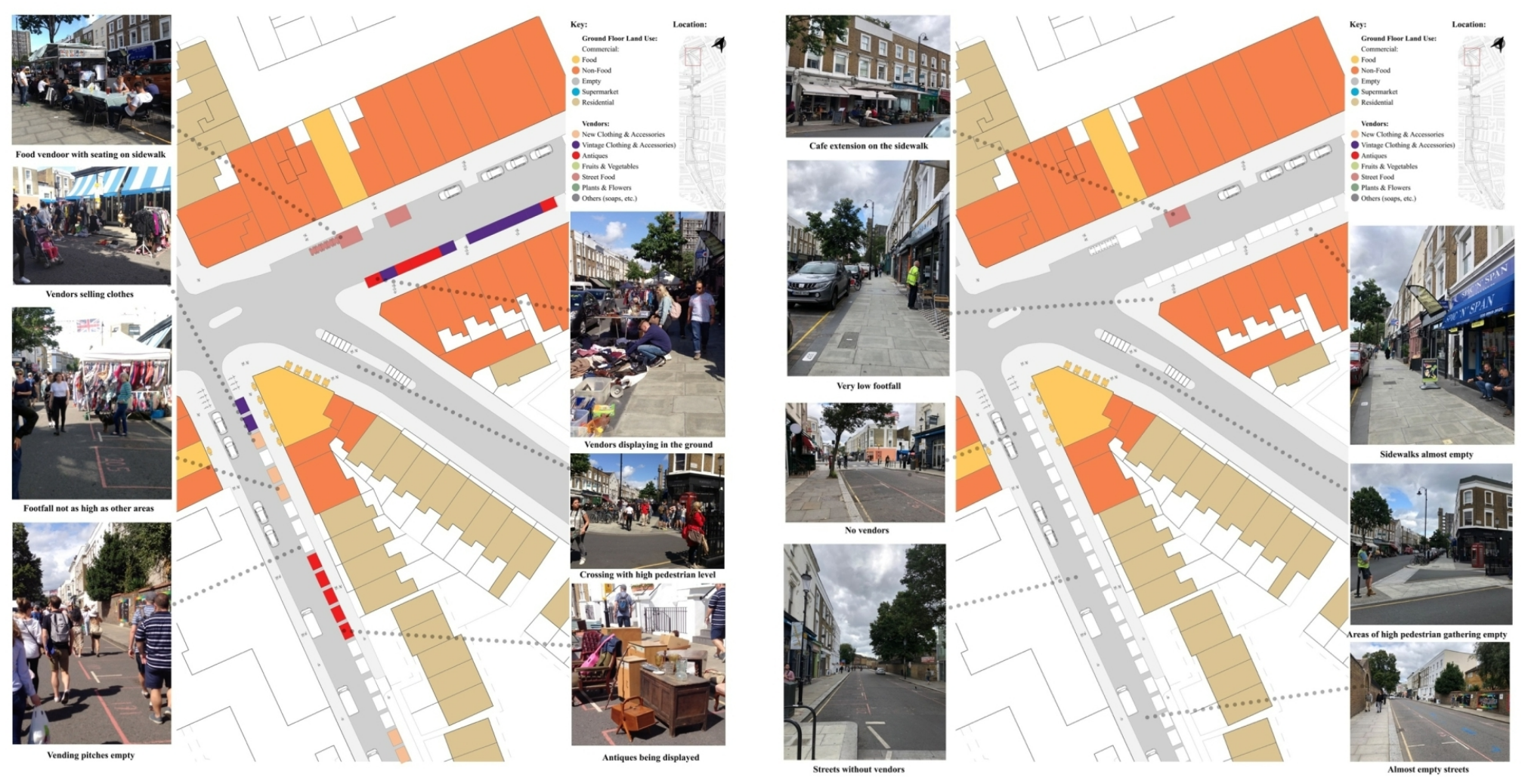


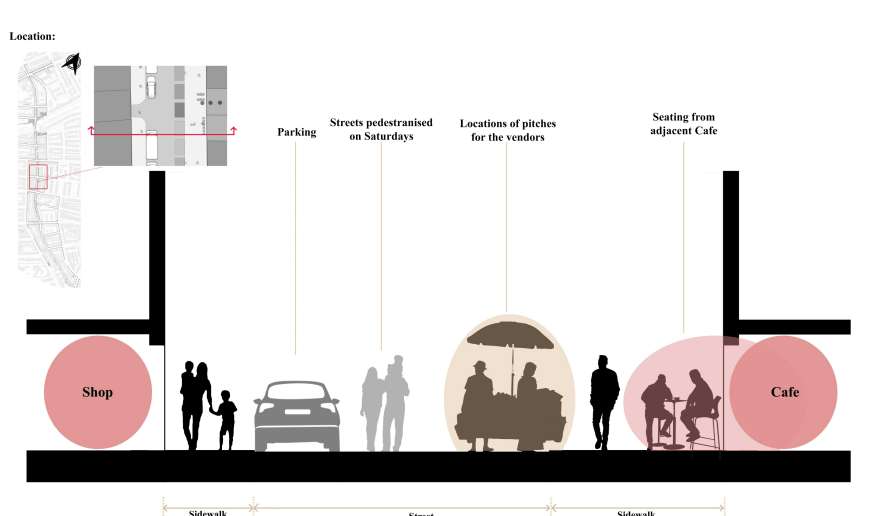




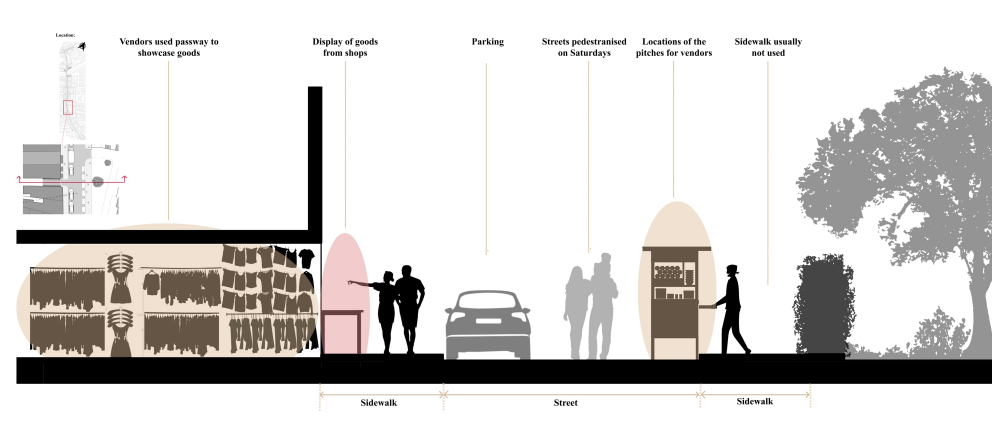

28

29

30

31

32

33

34

35

36

37

38

39

40 


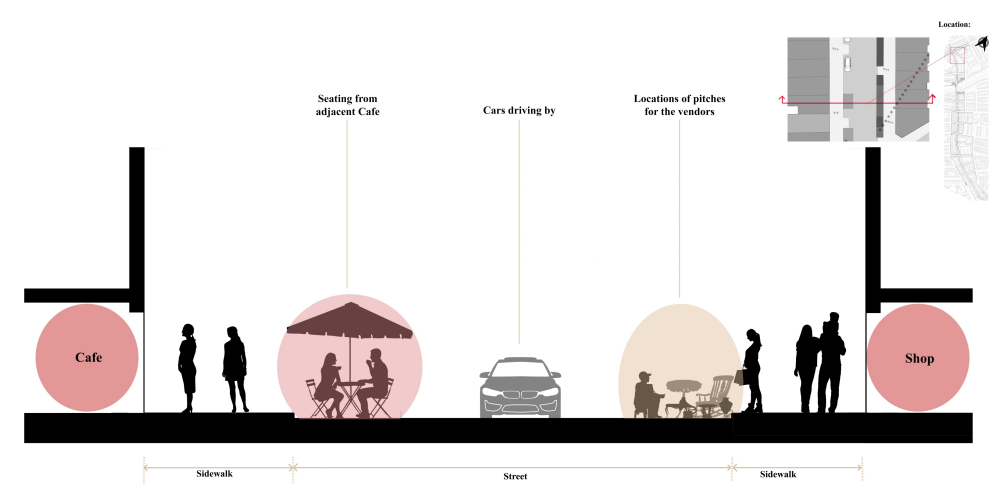

